\title{
ISOLASI BAKTERI ASAM LAKTAT DARI BEKASAM IKAN PATIN DAN POTENSI ANTIMIKROBANYA TERHADAP BEBERAPA BAKTERI PATOGEN
}

\author{
Retno Tri Astuti $^{a}$, Hefti Salis Yufidasari ${ }^{a}$, Happy Nursyam ${ }^{a}$, Jessica Della G.B. ${ }^{a}$ \\ ${ }^{a}$ Fakultas Perikanan dan Ilmu Kelautan, Universitas Brawijaya, Malang, 553512, Indonesia \\ * Corresponding author : retnoastuti@ub.ac.id
}

\begin{abstract}
ABSTRAK
Bekasam merupakan produk fermentasi spontan asal Indonesia yang terbuat dari ikan air tawar dengan tambahan garam dan sumber karbohidrat. Proses fermentasi bekasam umumnya melibatkan bakteri asam laktat yang memproduksi berbagai senyawa yang berperan dalam pembentukan rasa dan aroma produk serta mencegah kerusakan/pembusukan produk. Penelitian ini bertujuan untuk melakukan isolasi bakteri asam laktat asal bekasam ikan patin dan menguji aktivitas antagonisnya terhadap E. coli, Salmonella dan S. aureus. Parameter yang digunakan dalam pemilihan isolat potensial adalah aktivitas antagonisnya terhadap bakteri patogen dengan metode double layer dan difusi agar, serta memenuhi karakteristik bakteri asam laktat berdasarkan pewarnaan gram, uji katalase dan produksi gas dari glukosa. Hasil uji antibakteri menunjukkan sebanyak $58,3 \%, 66,67 \%$ dan $91,67 \%$ total BAL memiliki aktivitas antibakteri terhadap E. coli, Salmonella dan $S$. aureus. Tiga isolat BAL dengan aktivitas tertinggi berturut-turut adalah isolat HRB.1.10; HRB.1.7; dan HRB.1.11. Ketiga isolat BAL tersebut merupakan bakteri gram positif, tidak memiliki aktivitas katalase dan tidak menghasilkan gas pada media mengandung glukosa.
\end{abstract}

Kata kunci: Bekasam, Bakteri Asam Laktat, Antibakteri, Fermentasi

\begin{abstract}
Bekasam is a fermented product from Indonesia, made from fish, salt and rice or other carbohydrate sources. Fermentation process of bekasam mostly involve lactic acid bacteria that contribute in formation of the taste and aroma of the product and prevent product damage or rotting by producing antibacterial properties. The aim of this study is to isolate lactic acid bacteria from bekasam and to determine their antagonistic activity against E. coli, Salmonella and $S$. aureus. The parameters used in the selection of potential isolates were the antagonistic activity by double layer and agar diffusion methods, and its characteristics as lactic acid bacteria based on gram staining, catalase test and gas production. The results of the antibacterial test showed that $58.3 \%, 66.67 \%$ and $91.67 \%$ of total LAB perform antibacterial activity against E. coli, Salmonella and S. aureus, respectively. Isolates HRB.1.10; HRB.1.7; and HRB.1.11. showed the highest antibacterial activity. Those isolates were determined as gram-positive bacteria, did not have catalase activity and did not produce gas in media containing glucose, which is in accordance with the characteristics of lactic acid bacteria.
\end{abstract}

Keywords: Bekasam, Lactic Acid Bacteria, Antibacterial, Fermentati 


\section{PENDAHULUAN}

Indonesia merupakan negara yang kaya akan produk-produk olahan ikan berbasis ikan, salah satunya adalah bekasam. Bekasam adalah produk fermentasi ikan dengan rasa asam khas dan banyak dibuat di daerah Sumatra Selatan dan Kalimantan Selatan. Fermentasi bekasam umum dilakukan melalui fermentasi spontan dimana kondisi lingkungan dan bahan yang digunakan sangat berpengaruh terhadap komposisi mikroorganisme di dalamnya [1].

Pertumbuhan mikroorganisme selama proses fermentasi bekasam dibatasi dengan penambahan garam dan sumber karbohidrat [2]. Penambahan garam berfungsi sebagai seleksi dan membatasi pertumbuhan mikroorganisme sedangkan sumber karbohidrat biasanya berupa nasi akan dimanfaatkan oleh bakteri tertentu, umumnya golongan bakteri asam laktat, sebagai sumber energi.

Kelompok bakteri asam laktat (BAL) dominan pada produk fermentasi ikan yang ditambahkan sumber karbohidrat. BAL berperan penting dalam mencegah pembusukan dan memastikan keamanan produk, selain juga menyebabkan perubahan rasa, aroma maupun tekstur selama proses fermentasi [3]. Beberapa penelitian pada produk fermentasi ikan serupa bekasam yang berasal dari Thailand melaporkan bakteri asam laktat sebagai mikroba dominan. Pertumbuhan BAL mengakibatkan penurunan $\mathrm{pH}$ yang mencegah kerusakan/pembusukan produk [4]. Bakteri asam laktat juga dapat memproduksi beberapa senyawa seperti asam organik, hidrogen peroksida dan bakteriosin yang berpotensi sebagai senyawa antimikroba [5] [6].
Antibakteri merupakan zat yang dapat menghambat pertumbuhan atau mematikan bakteri. Mekanisme kerja dari senyawa antibakteri dapat berbeda-beda, diantaranya dengan menghambat sintesis dinding sel, menghambat keutuhan permeabilitas dinding sel bakteri, menghambat kerja enzim, dan menghambat sintesis asam nukleat dan protein [7]. Bakteriosin diketahui dapat menurunkan laju pertumbuhan bakteri patogen seperti Clostridium, Listeria, Staphylococcus, Bacillus spp.,Brochotrix, Aeromonas, dan Vibrio spp. [8]. Meskipun demikian, informasi mengenai karakterisasi produk bekasam termasuk dinamika dan potensi antimikroba yang terkandung di dalamnya masih terbatas.

Penelitian ini bertujuan untuk mengisolasi bakteri asam laktat asal bekasam serta potensinya sebagai antibakteri terhadap patogen pangan. Meskipun berbagai senyawa antimikroba dan antibiotik telah diteliti dan digunakan untuk manusia, umumnya ditujukan pada kondisi pengobatan infeksi. Antimikroba yang berasal dari bakteri asam laktat dianggap aman untuk dikonsumsi oleh manusia karena statusnya sebagai GRAS (generally recognized as safe). Penggunaan kultur BAL maupun senyawa yang dihasilkannya menarik untuk dikembangkan dalam upaya pengendalian mikroorganisme patogen dan pembusuk, serta untuk dimanfaatkan sebagai bahan pengawet makanan alami (biopreservative).

\section{METODE PENELITIAN}

\section{a. Waktu dan Tempat Penelitian}

Penelitian ini dilakukan pada bulan Juli hingga November 2020, bertempat di Laboratorium Keamanan Pangan FPIK Universitas Brawijaya. 


\section{b. Alat dan Bahan}

Alat yang digunakan pada penelitian ini adalah pisau, talenan, baskom, toples kaca, cawan petri, bunsen, inkubator, laminary flow, jarum ose, timbangan digital, kaca preparat, mikroskop, tabung reaksi, penggaris.

Bahan yang digunakan pada penelitian ini adalah ikan patin, garam, nasi putih, media NA, media MRSA, $\mathrm{CaCO}_{3}$, pewarna safranin, kristal violet, $\mathrm{H}_{2} \mathrm{O}_{2}$, glukosa.

\section{c. Pembuatan Bekasam}

Pembuatan bekasam dilakukan dengan metode dan komposisi yang didasarkan pada komunikasi pribadi dengan pembuat bekasam dari kota Palembang, Sumatera Selatan. Bekasam yang digunakan dibuat dengan menggunakan ikan patin. Ikan patin hidup dimatikan dengan cepat kemudian disiangi dengan membuang bagian kepala, insang, dan isi perut. Ikan dipotongpotong melintang, dicuci dengan air mengalir dan ditiriskan hingga kering. Garam dan nasi putih ditambahkan sebanyak $15 \%$ dan $25 \%$ dari total berat ikan, kemudian diratakan ke seluruh tubuh ikan. Campuran ikan-garam dan nasi dimasukkan ke dalam toples kaca dan ditutup rapat lalu difermentasi pada suhu ruang selama 8 hari [18].

\section{d. Isolasi Total Bakteri dan Bakteri Asam Laktat}

Total koloni bakteri ditumbuhkan pada media Nutrient Agar (NA) dan dihitung untuk mengetahui jumlah bakteri aerobik. Sampel yang sama digunakan untuk menumbuhkan bakteri asam laktat pada media de Man Rogosa Sharper Agar (MRSA) [9]. Bakteri yang tumbuh pada media MRSA diisolasi dan dimurnikan pada media agar yang baru dan diinkubasi pada suhu $37^{\circ} \mathrm{C}$ selama 48 jam [10].

\section{e. Penapisan Aktivitas Antibakteri}

Pengujian aktivitas antibakteri isolat terduga BAL dilakukan terhadap tiga bakteri uji yang merupakan patogen pangan, yaitu Salmonella, Escherichia coli dan Staphylococcuc aureus serta satu bakteri patogen pada ikan air tawar yaitu Aeromonas sp. Pengujian aktivitas antibakteri dilakukan dengan metode double layer pada media MRSA. Masingmasing bakteri uji disuspensikan pada media NA dan dituangkan pada permukaan kultur bakteri asam laktat pada media MRSA. Kultur diinkubasi pada suhu $37^{\circ} \mathrm{C}$ selama 24 jam. Bakteri asam laktat yang memiliki kemampuan penghambatan terhadap bakteri uji akan menunjukkan zona bening di sekeliling koloninya. Selanjutnya dilakukan verifikasi terhadap tiga isolat BAL yang menunjukkan aktivitas penghambatan yang relatif besar dan berkerja pada semua bakteri patogen yang digunakan.

\section{f. Verifikasi Bakteri Asam Laktat}

Verifikasi BAL terhadap tiga isolat paling potensial dilakukan meliputi bentuk dan motilitas sel, pewarnaan gram, pengujian katalase dan produksi gas pada media mengandung glukosa. Untuk pewarnaan gram, bakteri difiksasi pada kaca objek. Pewarnaan pertama dilakukan dengan kristal violet sebanyak 2-3 tetes dan didiamkan selama satu menit. Objek dicuci dengan aquadest, dikeringkan dan ditetesi dengan gram's iodine. Setelah dicuci dengan aquadest dan dikeringanginkan, objek ditetesi dengan alkohol (decolorizer) kemudian dicuci dengan aquadest. Pewarnaan terakhir menggunakan safranin 0.5\%. Pada 1000x, bakteri gram positif akan berwarna ungu dan bakteri negatif terlihat berwarna merah [11]. 
Uji katalase dilakukan dengan mengambil sedikit koloni bakteri menggunakan stik kayu kemudian diletakkan diatas kaca preparat. Tiga tetes $\mathrm{H}_{2} \mathrm{O}_{2} 3 \%$ ditambahkan pada objek dan dibiarkan beberapa menit. Pembentukan gelembung udara menunjukkan aktivitas katalase positif, sedangkan bakteri dengan katalase negatif tidak akan membentuk gelembung udara [12].

\section{g. Aktivitas Antibakteri BAL Potensial dengan Metode Difusi Agar}

Tiga isolat BAL paling potensial selanjutnya ditumbuhkan pada media MRS cair dan digunakan untuk pengujian menggunakan metode difusi agar. Isolat BAL potensial diinokulasi pada media MRS cair dan diinkubasi pada suhu $30^{\circ} \mathrm{C}$ selama 24 jam. Selanjutnya supernatan dipisahkan dari sel bakteri dengan sentrifugasi selama 15 menit. Supernatan diambil dan difiltrasi menggunakan mikrofilter (diameter pori $0,22 \mathrm{uM}$ ) sehingga diperoleh supernatan bebas sel.

Media MHA digunakan untuk menumbuhkan bakteri patogen dengan metode pour plate. Setelah agar membeku, sumuran dibuat pada tiga titik dengan diameter $5 \mathrm{~mm}$. Selanjutnya, sebanyak 75 uL supernataan bebas sel dari masingmasing BAL potensial diintroduksikan ke dalam sumuran. Inkubasi dilakukan selama 18 jam. Zona penghambatan terhadap bakteri uji diukur dengan menghitung diameter zona bening yang terbentuk di sekeliling sumuran [6].

\section{HASIL DAN PEMBAHASAN}

Fermentasi, bersama dengan pengeringan dan penggaraman merupakan metode pengawetan pangan tertua di dunia. Minat dan pengakuan terhadap produk pangan fermentasi semakin meningkat seiring dengan perkembangan peradaban dan pengetahuan mengenai nutrisi pangan dan aktivitas fungsionalnya [13].

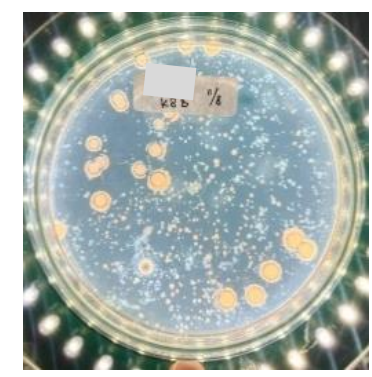

Gambar 1. Hasil isolasi total bakteri sampel bekasam ikan patin pada media PCA

Pada penelitian ini, bekasam ikan patin digunakan sebagai sampel untuk isolasi total culturable bacteria dan bakteri asam laktat. Total bakteri dari bekasam ditumbuhkan pada media Nutrient Agar (NA) dengan metode pour plate dan diinkubasi selama 24 jam (Gambar 1). Sampel bekasam yang sama diinokulasikan pada media de Mann Rogosa Sharpe (MRS) agar untuk mendapatkan isolat bakteri yang kemungkinan merupakan kelompok bakteri asam laktat (Gambar 2).

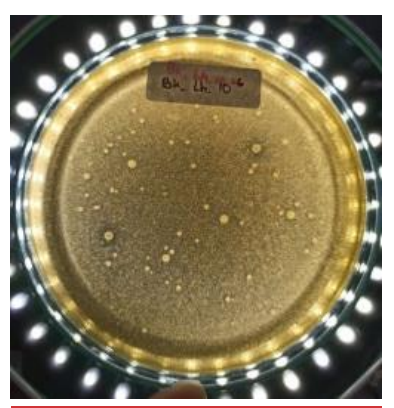

Gambar 2. Hasil isolasi bakteri asam laktat sampel bekasam ikan patin pada media MRS agar

Dari perhitungan pada masingmasing media tersebut diperoleh angka total bakteri sebesar $7,8 \times 10^{7}$ dan $1,2 \times 10^{8}$ untuk total bakteri asam laktat. Jenis dan jumlah bakteri asam laktat pada fermentasi bekasam kemungkinan dipengaruhi oleh bahan baku yang digunakan. Jenis BAL dapat bervariasi tergantung pada jenis ikan, habitat dan lokasi geografisnya [14]. 

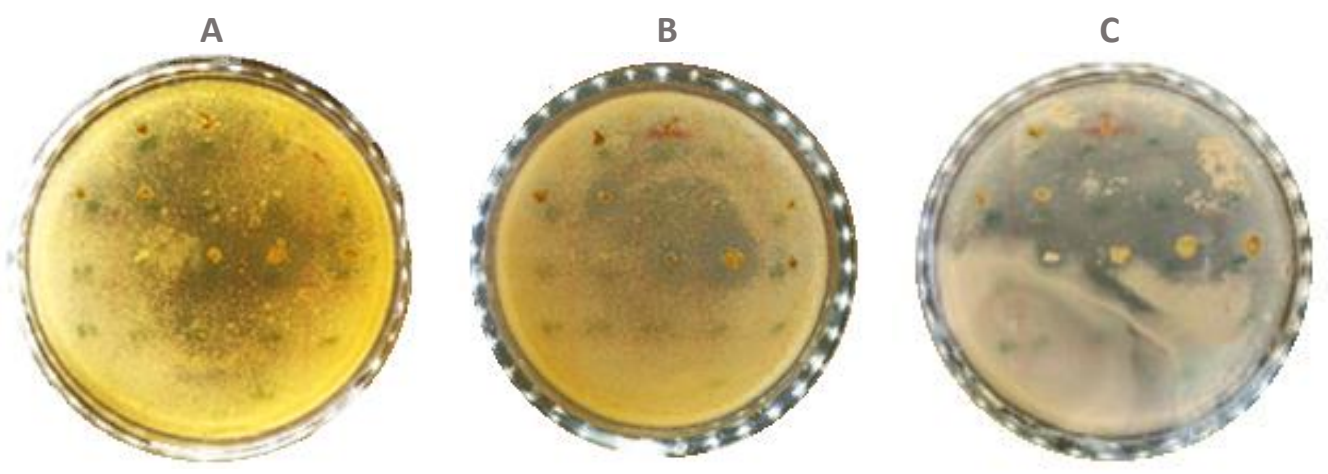

Gambar 3. Aktivitas antagonis bakteri asam laktat asal bekasam ikan patin terhadap bakteri patogen E. coli (A), Salmonella (B) dan S. aureus (C)

Sebanyak 20 isolat bakteri dari media MRS agar diambil dan diremajakan pada media yang sama. Setelah peremajaan, sebanyak dua belas isolat bakteri asam laktat dapat tumbuh dengan baik dan stabil. Seluruh isolat diuji potensi aktivitas antibakterinya terhadap tiga patogen yang berasosiasi dengan penyakit yang berasal dari makanan yaitu Escherichia coli, Salmonella sp. dan Staphylococcus aureus dengan metode double layer (Gambar 3).

Hasil pengujian menunjukkan hampir semua isolat BAL yang diuji memiliki aktivitas antibakteri dengan intensitas yang berbeda-beda. Sebanyak tujuh $(58,3 \%)$ BAL menunjukkan penghambatan terhadap $E$. coli. Sedangkan delapan $(66,67 \%)$ dan sebelas $(91,66 \%)$ isolat BAL menghambat masing-masing terhadap Salmonella dan S. aureus (Tabel 1).

Enam isolat BAL memiliki aktivitas penghambatan terhadap ketiga bakteri patogen sekaligus. Satu BAL lainnya menghambat hanya satu jenis bakteri patogen dan dua BAL lainnya menghambat 2 jenis bakteri patogen. Dari hasil uji double layer, tiga isolat $\mathrm{BAL}$ yaitu HRB.1.10; HRB.1.7; dan HRB.1.11 menunjukkan zona penghambatan terbesar dan stabil terhadap tiga bakteri patogen yang diujikan.
Tabel 1. Rincian aktivitas penghambatan bakteri patogen oleh isolat bakteri asam laktat

\begin{tabular}{lccc}
\hline Kode BAL & A & B & C \\
\hline HRB.1.1 & 0 & 1 & 1 \\
\hline HRB.1.2 & 0 & 1 & 1 \\
\hline HRB.1.3 & 1 & 1 & 1 \\
\hline HRB.1.4 & 0 & 0 & 0 \\
\hline HRB.1.5 & 0 & 0 & 1 \\
\hline HRB.1.6 & 0 & 0 & 1 \\
\hline HRB.1.7 & 1 & 1 & 1 \\
\hline HRB.1.8 & 1 & 1 & 1 \\
\hline HRB.1.9 & 1 & 1 & 1 \\
\hline HRB.1.10 & 1 & 1 & 1 \\
\hline HRB.1.11 & 1 & 1 & 1 \\
\hline HRB.1.12 & 1 & 0 & 1 \\
\hline Jumlah isolat & 7 & 8 & 11 \\
menghambat & $(58,33 \%)$ & $(66,67 \%)$ & $(91,67 \%)$ \\
\hline
\end{tabular}

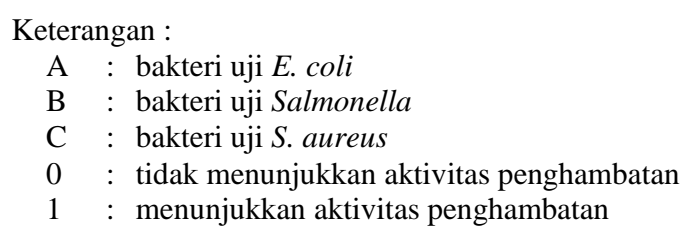

Sebelum diuji lebih lanjut dengan metode difusi agar, dilakukan verifikasi untuk memastikan isolat yang diperoleh merupakan bakteri asam laktat. MRS agar merupakan media yang dikembangkan terutama untuk menumbuhkan golongan Lactobacilli dan seluruh kelompok bakteri asam laktat. Media ini terbukti memiliki produktivitas yang baik untuk hampir semua bakteri asam laktat. Kondisi media 
dengan $\mathrm{pH}$ rendah berkisar 5,7 dan penambahan asam sorbat $0,14 \%$ menjadikan media bersifat selektif. Meskipun demikian, beberapa jenis bakteri lain mungkin tumbuh pada media MRS agar yang dapat dibedakan dari bakteri asam laktat dengan pengujian lebih lanjut.

Verifikasi BAL dilakukan dengan pengujian pewarnaan gram dan pengamatan di bawah mikroskop, uji katalase dan produksi gas. Hasil karakterisasi isolat bakteri asam laktat dapat dilihat pada Tabel . Hasil pengamatan menunjukkan bahwa ketiga bakteri potensial merupakan bakteri gram positif (Gambar 4). Hasil pengujian selengkapnya disajikan pada Tabel 2.

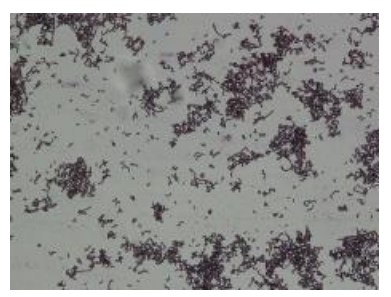

Gambar 4.Hasil pewarnaan gram bakteri asam laktat potensial

Kelompok bakteri asam laktat secara umum dijelaskan sebagai golongan bakteri gram positif, dapat berbentuk kokus atau batang, tidak menghasilkan spora, memproduksi asam laktat, katalase negatif, anaerob fakultatif, toleran terhadap asam dan memiliki $\% \mathrm{G}+\mathrm{C}$ yang relatif rendah [15].

Tabel 2. Karakterisasi Tiga Isolat Bakteri Asam Laktat Potensial

\begin{tabular}{lccc}
\hline Pengujian & HRB.1.10 & HRB.1.7 & HRB.1.11 \\
\hline Gram & Positif & Positif & Positif \\
\hline $\begin{array}{l}\text { Bentuk } \\
\text { sel }\end{array}$ & Kokus & Batang & Kokus \\
\hline Motilitas & Non & Non & Non \\
\hline $\begin{array}{l}\text { Produksi } \\
\text { gas }\end{array}$ & Negatif & Negatif & Negatif \\
\hline Katalase & Negatif & Negatif & Negatif \\
\hline
\end{tabular}

Hasil pengujian pada Tabel 2, menunjukkan bahwa tiga isolat potensial yang diperoleh pada penelitian ini memiliki karakteristik sebagai BAL. Ketiga isolat BAL selanjutnya diujikan kembali terhadap bakteri E. coli, Salmonella dan $S$. aureus dengan metode difusi agar untuk mengetahui zona pengahambatan dengan lebih jelas. Aktivitas antibakteri diuji menggunakan supernatan bebas sel dari tiga isolat BAL potensial secara terpisah. Isolat HRB.1.10 menunjukkan zona penghambatan terbesar yaitu terhadap bakteri $S$. aureus $(2,3 \mathrm{~mm})$ diikuti dengan penghambatannya terhadap E. coli $(2,1$ mm) (Tabel 3).

Tabel 3. Aktivitas antibakteri tiga BAL potensial terhadap bakteri patogen uji

\begin{tabular}{cccc}
\hline \multirow{2}{*}{ BAL } & \multicolumn{3}{c}{ Zona hambat $(\mathbf{m m})$} \\
\cline { 2 - 4 } & A & B & C \\
\hline HRB.1.10 & 2,1 & 1,6 & 2,3 \\
\hline HRB.1.7 & 1,8 & 1,2 & 1,7 \\
\hline HRB.1.11 & 1,3 & 0,9 & 2,0 \\
\hline A $\quad:$ bakteri uji E. coli & & \\
B : bakteri uji Salmonella & & \\
C : bakteri uji S. aureus &
\end{tabular}

Aktivitas antibakteri isolat BAL kemungkinan merupakan faktor pengawet (selain penambahan garam) selama proses fermentasi bekasam. Metabolisme BAL menghasilkan berbagai senyawa asam organik yang dapat berperan sebagai antimikroba penting. Dari waktu ke waktu, asam organik telah banyak dimanfaatkan untuk keperluan pengawetan dan keamanan pangan [16].

Beberapa asam organik yang dihasilkan oleh BAL, seperti asam laktat dan asam asetat memberikan situasi asam yang tidak mendukung bagi pertumbuhan mikroorganisme patogen dan pembusuk secara umum. 
Asam organik secara umum mengganggu pertumbuhan mikoba dengan mempengaruhi potensial membran, transport material di dalam sel, dan menghambat kinerja metabolik sel [5]. Selain itu, beberapa jenis BAL dapat menghasilkan substansi antimikroba lain seperti $\mathrm{CO}_{2}$, bakteriosin dan hidrogen peroksida $\left(\mathrm{H}_{2} \mathrm{O}_{2}\right)$ [16].

Substansi antimikroba dari BAL, maupun BAL yang menghasilkan senyawa antimikroba seperti bakteriosin, secara umum dianggap aman untuk dikonsumsi oleh manusia dan telah digunakan terutama dalam upaya pengawetan makanan tanpa adanya catatan bahaya atau keracunan yang ditimbulkan.

Dalam konteks pangan fermentasi, Bakteri asam laktat juga berkontribusi dalam perubahan tekstur, aroma dan rasa produk. Berbagai jenis enzim dihasilkan oleh kelompok bakteri asam laktat dalam proses fermentasi pangan mulai dari enzim proteolitik, urease, lipase hingga pendegradasi polisakarida [17].

Meskipun masih berada pada tahapan awal, hasil dari penelitian ini berpotensi menjadi dasar pengembangan studi lebih lanjut mengenai protensi agen biologis fungsional yaitu bakteri asam laktat. Konsorsium BAL yaitu HRB.1.10; HRB.1.7; dan HRB.1.11 maupun metabolit yang dihasilkannya berpotensi untuk digunakan sebagai starter dalam proses fermentasi bekasam untuk menghasilkan produk dengan karakteristik rasa, aroma, tekstur dan masa simpan yang lebih baik dan stabil. BAL secara umum dikategorikan sebagai generally recognized as safe (GRAS) sehingga metabolit yang dihasilkan berpotensi untuk dikembangkan sebagai kandidat pengawet pangan.

\section{KESIMPULAN}

Isolat bakteri asam laktat asal bekasam ikan patin telah diisolai pada penelitian ini. Sejumlah dua belas isolat bakteri dimurnikan dari media MRSA. Hasil uji antibakteri menunjukkan sebanyak 58,33\%, 66,67\% dan 91,67\% total BAL memiliki aktivitas antibakteri terhadap E. coli, Salmonella dan $S$. aureus. Tiga isolat BAL yaitu HRB.1.10; HRB.1.7; dan HRB.1.11 menunjukkan zona penghambatan terbesar dan stabil terhadap tiga bakteri patogen yang diujikan. Isolat tersebut seluruhnya bersifat gram positif, katalase negatif dan tidak menghasilkan gas pada media mengandung glukosa.

\section{UCAPAN TERIMA KASIH}

Ucapan terima kasih disampaikan kepada PNBP FPIK UB yang telah mendanai penelitian ini melalui Hibah Penelitian Dosen Fakultas Perikanan dan Ilmu Kelautan tahun 2020.

\section{DAFTAR PUSTAKA}

[1] Wikandari, P. R., Suparmo., Yustinus, M., Endang, S. R. Potensi bakteri asam laktat yang diisolasi dari bekasam sebagai penghasil angiotensin converting enzyme inhibitor pada fermentasi "bekasamlike" produk. AGRITECH. 32(3):17. 2012.

[2] Lestari S, Rinto, Huriyah SB. Peningkatan sifat fungsional bekasam menggunakan starter Lactobacillus acidophilus. Jurnal Pengolahan Hasil Perikanan Indonesia. 21(1): 179-187. 2018.

[3] Hugas M. Bacteriocinogenic lactic acid bacteria for the biopreservation meat and meat products. Meat Science. 49: S139-S150. 1998. 
[4] Ostergaard A et al. Fermentation and spoilage of som-fak a Thai low-salt fish product. Trop Sci 38: 105-112. 1998.

[5] Ross RP, Morgan S, Hill C. Preservation and fermentation: past, present and future. Int $J$ Food Microbiol 79:3-16. 2002.

[6] Diop MB et al. Bacteriocin producers from traditional food products. Biotechnol Agron Soc Environ 11: 275-281. 2007.

[7] Dwidjoseputro. Dasar-Dasar Mikrobiologi. Djambatan, Yogjakarta. 1980.

[8] Abubakar dan Arpah M. Pengaruh suhu produksi terhadap aktivitas ekstrak kasar bakteriosin dari berbagai galur Lactobacillus sp. dalam menghambat Escherichia coli dan Staphylococcus aureus. Buletin Peternakan. 39(3): 189-198. 2015.

[9] Veljovic, K., A. Terzic-Vidojevic., M. Vukasinovic,I. Strahinic,J. Begovic,J. Lozo,M. Ostojic,L. Topisirovic. Preliminary characterization of lactic acid bacteria isolated from Zlatar cheese. Journal of Applied Microbiology. 103(6):2142-2152. 2007.

[10] Tanasupawat, S., Okada, S., Komagata, K. Lactic acid bacteria found in fermented fish in Thailand. J Gen Appl Microbiol. 44(3):193200. 1998.

[11] Tripathi N., Sapra A. Gram Staining. StatPearls Publishing LLC. 2021

[12] Reiner K. Catalase Test Protocol. American Society of Microbiology. 2016

[13] Prajapati JB, Nair BM. The history of fermented foods. Dalam: Farnworth ER [ed]. Handbook of
Fermented Functional Foods. CRC Press Taylor \& Francis Group. 2003

[14] Ringo E. Lactic acid bacteria in fish and fish farming. Dalam Salminen S, Wright SV, Ouwehand A [eds]. Lactic Acid Bacteria. Microbiological and Functional Aspects. Third edition, Revised and Expanded. New York:Marcel Dekker, Inc. 2004

[15] Hutkins, R.W. Microbiology and Technology of Fermented Foods. Blackwell Publishing Asia. Australia. 2006.

[16] Ouwehand AC, Vesterlund S. Antimicrobial components from lactic acid bacteria. Dalam Salminen S, Wright SV, Ouwehand A. [eds]. Lactic Acid Bacteria. Microbiological and Functional Aspects. Ed. ke-3, Revised and Expanded. New York: Marcel Dekker, Inc. 2004

[17] Matthews, A., Grimaldi, A., Walker, M., Bartowsky, E., Grbin, P., \& Jiranek, V. Lactic acid bacteria as a potential source of enzymes for use in vinification. Applied and environmental microbiology, 70(10):5715-5731. 2004. 